\title{
Metapopulation perspective to institutional fit: maintenance of dynamic habitat networks
}

\author{
$\underline{\text { Henna Fabritius }}^{1,2}$, Ari Jokinen $^{3}$ and Mar Cabeza $^{1}$
}

\begin{abstract}
Species living in metapopulations depend on connected habitat networks for their survival. If habitat networks experience fast temporal dynamics, species conservation requires preventing habitat discontinuities that could lead to metapopulation extinctions. However, few institutional solutions exist for the maintenance of spatiotemporally dynamic habitat networks outside of protected areas. To explore this often neglected problem, we studied the institutional fit of false heath fritillary (Melitaea diamina) conservation in Finland from the perspective of conservation institutions' ability to manage early successional habitat availability for this endangered species. We identified four institutional arrangements that enable effective conservation management of dynamic habitat networks: (1) acknowledgment of habitat dynamics, (2) monitoring of and responding to changes in the habitat network, (3) management of resources for fluctuating resource needs, and (4) scaling of activities through flexible collaborations. These arrangements provide the institutional flexibility needed for responding to temporal changes in habitat availability.
\end{abstract}

Key Words: conservation; dynamic habitat networks; false heath fritillary; functional fit; habitat overgrowth; institutional fit; Melitaea diamina; metapopulation dynamics; spatial fit; temporal fit

\section{INTRODUCTION}

\section{Conservation of dynamic habitat networks}

Species living in metapopulations depend on the continuous availability of connected habitat patch networks for their survival (Hanski 1994, Hanski and Ovaskainen 2000, Cabeza 2003). Habitat patch networks may undergo gradual degradation (Mortelliti et al. 2010) or loss (Bulman et al. 2007) of habitat patches because of human land use activities. Additionally, climate change may cause habitat patch networks to shift gradually toward the poles (Radchuck et al. 2014). In particular, habitat patch networks can be dynamic for species that occupy early successional habitats, in which case individual habitats may emerge and disappear depending on local disturbance patterns and the process of succession (Johst et al. 2011). As the intensification of human land use has caused changes to disturbance regimes across ecosystems (Lytle and LeRoy Poff 2004, Enck and Odato 2008, Lourival et al. 2011), the availability of early successional habitats has decreased in many ecosystems (Thompson and DeGraaf 2001, Halada et al. 2011), and this has caused the endangerment of early successional species (Askins 2001, Dettmers 2003, Long 2009). These developments have resulted in spatially explicit conservation planning needs for species that live in spatiotemporally changing habitat networks (Van Teeffelen et al. 2012).

When conservation plans have to be designed for dynamic habitat networks, specific complexities emerge because of their transitional nature. If habitat patches are short lived, temporal variations in habitat regeneration rates may cause temporal fluctuations in habitat availability (Moilanen et al. 2014). Such fluctuations have been shown to increase extinction risks for species that live in dynamic habitat networks because they can cause synchronized collapses of local populations (Boughton and
Malvadkar 2002, Johst et al. 2011, Van Teeffelen et al. 2012). Conservation of dynamic habitat networks may therefore require management of constant spatiotemporal habitat availability for the species of interest, which may require facilitating maintenance activities at times and locations that best minimize habitat discontinuities, i.e., temporal gaps in habitat availability (Hanski 1999). These maintenance activities can include methods that delay or restart succession to increase the availability of the successional stage of interest, e.g., mowing or grazing. However, few institutional solutions have been developed for the purpose of such spatiotemporal planning. Agri-environmental schemes (European Commission 2005, Kleijn et al. 2006, Arponen et al. 2013) are used to maintain habitat networks for demanding early successional species, but these institutions are restricted in their ability to prioritize spatial connectivity of habitats (Schouten et al. 2013). Fire management institutions (Richards et al. 1999, Keeley and Fotheringam 2001, Stewart et al. 2005) provide examples of institutions that aim at providing continuums of early successional habitats. Their design and performance have been studied from a spatially implicit perspective (Hansen 2014).

\section{Institutional fit of habitat network maintenance organizations} Institutional fit has been used as a conceptual framework to study how well institutions are aligned with the realities they manage or govern (Young 2003, Folke et al. 2007, Cox 2012). Fit depends on the governance or management targets of institutions and on the political and cultural setting (Haller et al. 2013) and may entail multiple different measures of fit simultaneously (Lebel et al. 2013). In the case of natural resource management, an institution's performance may be measured in terms of its ability to increase the spatial resilience of the system against perturbations (Bengtsson et al. 2003, Allen et al. 2016), which reduces temporal variability in the flow of the resource into the economy (Walker et al. 2004, Folke et al. 2007, Ostrom 2007). Fit

\footnotetext{
${ }^{1}$ Department of Biosciences, University of Helsinki, ${ }^{2}$ Swedish Species Information Centre, Swedish University of Agricultural Sciences, ${ }^{3}$ Faculty of Management (Environmental Policy), University of Tampere
} 
has been estimated qualitatively based on interviews and policy documents (Munck af Rosenchöld et al. 2014), by calculating similarity metrics between ecological systems and policy descriptions (Ekstrom and Young 2009), or by counting fit measures from expert questionnaire replies (Lebel et al. 2013).

Institutional fit has been measured from spatial (Folke et al. 2007, Moss 2012, Lebel et al. 2013), temporal (Pérez-Nordtvedt et al. 2008, Munck af Rosenschöld et al. 2014), and functional (Ekstrom and Young 2009) perspectives. Functional fit measures whether the key functions of the managed system are addressed by the managing institution (Ekstrom and Young 2009), whereas spatial fit refers to mismatches in the spatial extent of administration versus that of managed ecological systems (Folke et al. 2007). Temporal fit refers to the timing of institutional activities in relation to the temporal patterns in the biophysical environment they manage or respond to (Munck af Rosenschöld et al. 2014). Pérez-Nordtvedt et al. (2008) suggest the use of concepts of tempo and phase to characterize the length and timing of organizational and environmental cycles, such as cycles of technological improvement or governmental regulatory activities, to assess their temporal fit. Munck af Rosenschöld et al. (2014) use a wider concept of timescapes from Adam (2000), which includes the study of spatiotemporal pattern, sequence, and time frame of organizational activities. Spatial and temporal fit have also been analyzed simultaneously (Cash et al. 2006).

Past works have proposed that in social-ecological systems prone to perturbations and dynamic changes, high institutional fit requires adaptive governance (Folke 2006). This requires an understanding of ecosystem dynamics, for instance of the feedback mechanisms that are critical in the maintenance of the spatial resilience of the system (Allen et al. 2016), management practices that respond to feedback, adaptive capacity to respond to surprise, and institutional flexibility (Folke 2006, Folke et al. 2007). In multiscale institutions, adaptive capacity may require interplay of actors of different scales, frameworks, and regimes (Paavola et al. 2009) and the existence of nested institutions (Folke 2006, Folke et al. 2007) that can bridge the functions of different actors at the right time to create social-ecological resilience (Lebel et al. 2006, Olsson et al. 2007, Green et al. 2015). High fit also requires acceptability of the institutions in the eyes of resource users and landowners (Hukkinen 2012, Farrell and Thiel 2013, Hiedanpää 2013), the attainment of which may require creating mechanisms that utilize their knowledge in the functioning of the institutions (Olsson et al. 2007). Power structures within multilevel governance institutions can maintain institutional misfit (Folke et al. 2007). Pérez-Nordtvedt et al. (2008) suggest that temporal fit of institutions depends on whether internal temporal cycles of the institutions can be reasonably synchronized with, or entrained to (Jokinen 2006), their external environment or whether dominant cycles within governance organizations act as pacers, also called zeitgebers (PérezNordtvedt et al. 2008), that maintain misfit.

We set out to identify institutional arrangements that enable effective conservation management of dynamic habitat networks. We assessed the performance of conservation institutions from the perspective of their ability to provide habitats that support stable, resilient population sizes of the species being conserved. This, based on the metapopulation theory, requires habitat networks of adequate connectivity (Cabeza 2003) and capacity (Hanski and Ovaskainen 2000) over time. We carried out a case study of the conservation of a Finnish endangered butterfly, the false heath fritillary Melitaea diamina (Lang, 1789), for which the primary documented cause of endangerment in Finland is the successional dynamics of its habitats, i.e., "overgrowing of meadows and other open habitats" (Rassi et al. 2010:40). We used thematic interviews and conservation reports to identify types and timings of activities in the Finnish national-level and regionallevel governmental conservation organizations with regard to false heath fritillary conservation. Finally, we collected expert estimates on the potential need of habitat maintenance for endangered Finnish species to estimate the generalizability of our findings. Based on the case study, we identified key institutional arrangements that enable effective conservation management of dynamic habitat networks.

\section{METHODS}

\section{Case study: false heath fritillary conservation in Finland}

The false heath fritillary is a moist meadow specialist that has, like many butterfly species, suffered from agricultural modernization and drainage of moist soils within the recent decades (Liinalaakso 2000, van Swaay et al. 2006). The false heath fritillary is listed as an endangered species (Rassi et al. 2010), a protected species, and a species under strict protection (Ministry of the Environment 1997) in Finland, the major cause of its endangerment being the fast successional dynamics of its habitats, i.e., "overgrowing of meadows and other open habitats" (category $\mathrm{N}$ ), in the absence of traditional land uses. Conservation planning for the false heath fritillary is complicated by the species' dependence on disturbed habitats, either human-maintained moist meadows or a dynamically changing network of suitable early successional fallows. Most false heath fritillary habitats appear on private agricultural land. Because false heath fritillary habitats are seldom occupied by other endangered species of regional interest, they are not the focus of habitat-focused conservation programs. The expected lifetime of an unprotected false heath fritillary habitat has been estimated to be 13.1 years, the quality of the habitat site starting to decrease 2-3 years after site maintenance because of the successional dynamics of the habitats (Fabritius and McBride 2017) and habitats requiring maintenance, e.g., mowing or grazing, at least every 5 years (Intke 2003).

False heath fritillary conservation in Finland focuses on the regional-level Centres of the Economic Development, Transport and the Environment (ELY centers), which hold the governmental authority to steer and monitor local and regional land use planning, to establish conservation areas on private land, and to enforce habitat demarcations and permits of exception related to the habitats of endangered species (Ministry of the Environment 2015, Centre for Economic Development, Transport and the Environment 2016). Based on the false heath fritillary distribution in Finland (Wahlberg 1998), matters related to the species are dealt with in the ELY centers of Pirkanmaa (Pirkanmaa region), South Ostrobothnia (Ostrobothnia and South Ostrobothnia regions), and southwest Finland (Satakunta region). At the central level of administration, the Ministry of the Environment formulates the environmental policies of the Finnish government, steers and resources the ELY centers in nature conservation, and 
guides the work carried out in the Finnish Environment Institute (SYKE), which conducts research and compiles environmental data. The Natural Heritage Services unit of Metsähallitus (Finnish Forestry Service) is responsible for nature conservation on state-owned land (Ministry of the Environment 2015).

\section{Thematic interviews and conservation reports}

We carried out thematic interviews between November 2014 and February 2015 to detail the goals, priorities, decision-making processes, collaborations, and practices of false heath fritillary conservation in Finland. The respondents included three senior advisers of the regional ELY centers that were in charge of the false heath fritillary conservation in their respective regions (Pirkanmaa, South Ostrobothnia, and southwest Finland), two civil servants in the Ministry of the Environment responsible for the funding decisions regarding governmental conservation funds, and a biologist at the Natural Environment Centre of SYKE who was responsible for regional prioritization meetings of endangered species. The interviewees covered key actors, and they were well aware of the basic ecology and conservation challenges of the false heath fritillary because of collaboration between the species-specific researchers and administration since Wahlberg $(1997,1998)$. We conducted the interviews by following a ready-made thematic interview frame (Appendix 1) that was different for the three groups of interviewees, i.e., the ELY centers, the Ministry of the Environment, and SYKE, but allowed the discussion to follow topics brought up by the respondents. Besides thematic interviews, we studied 14 reports of the regional environmental administration regarding the monitoring and restoration of false heath fritillary habitats.

We used content analysis to examine the interview data and conservation reports with regard to the decision-making processes, goals, practices, collaboration structures, and dependencies related to false heath fritillary conservation. First, we identified what information was available to conservation managers with regard to changes in the numbers, sizes, qualities, and locations of habitat patches in the false heath fritillary habitat network of their respective administrative areas. Next, we identified cyclical activities taking place in the conservation organizations regarding the identified habitat network dynamics and asked what set the tempo and phase of these activities. We also examined how these organizations applied formal legal framework versus adaptive governance in conservation (Garmestani et al. 2013). Finally, we asked the following questions to evaluate the institutional fit of conservation: Are conservation institutions able to identify and respond to decreasing habitat quality and availability within such time frames that can prevent habitat discontinuities for false heath fritillary metapopulations? Are conservation institutions able to prioritize, execute, or facilitate habitat maintenance, restoration, or generation at locations that are important for the spatiotemporal connectivity of the habitat network? Based on our findings, we identified key institutional arrangements that enable effective conservation management of dynamic habitat networks.

\section{Expert estimates on the generalizability of the study case}

To assess how common the conservation challenges identified in our case study are in the field of endangered species conservation in Finland, we estimated how many other endangered species in Finland, also threatened by the successional dynamics of their habitats, would be conserved using the same processes as the false heath fritillary because of a similar legal and conservation status. For this purpose, we extracted the numbers of endangered species, belonging to the categories vulnerable (VU), endangered (EN), and critically endangered (CR), from the Finnish Red List of Endangered Species 2010 (Rassi et al. 2010) that are also threatened by successional habitat dynamics (primary cause of endangerment $\mathrm{N}$ ) and that are categorized as species under strict protection. We then asked two taxon-specific experts to identify species in the resulting list that tend to occupy habitats that fall out of common habitat-specific conservation programs and would therefore need species-specific conservation measures for efficient conservation.

\section{RESULTS}

We found functional, spatial, and temporal misfits in the institutions that manage habitat availability for the false heath fritillary. Based on these findings, we identified four key institutional arrangements that enable effective maintenance of dynamic habitat networks: (1) acknowledgment of habitat dynamics, (2) monitoring of and responding to changes in the habitat network, (3) management of resources for fluctuating resource needs, and (4) scaling of activities through flexible collaborations. For each arrangement, we suggest key questions that can be used by conservation managers, public officials, and researchers to assess the extent of fit and causes of potential misfits in institutions that maintain dynamic habitat networks. The questions have been formulated so that, in each category, an increasing number of positive replies suggests increasing fit. Following the questions, we suggest guidelines for improving the institutional fit with regard to the questions presented.

\section{Acknowledgement of habitat dynamics}

For false heath fritillary conservation, a key source of institutional misfit arose from the limited acknowledgment of temporal habitat dynamics by formal conservation institutions. The legislative basis of false heath fritillary conservation, i.e., the species' status as a species of strict protection, was linked to a policy tool that enabled regional ELY centers to use a procedure of official habitat demarcations to restrict destructive activities at false heath fritillary habitats (Ministry of the Environment 1996). However, the respondents considered habitat demarcations a controversial tool for conserving sites prone to successional habitat dynamics because imposing limitations to private landowners' land use rights was expected to deteriorate private landowners' attitudes toward habitat maintenance. The status as a species of strict protection also enabled the Ministry of the Environment (1996) to prepare a program for reviving the species' populations, but such a program had not been prepared. None of the statuses of the false heath fritillary invoked such formal conservation policies that would have provided access to resources or tools for tackling habitat dynamics or for generating new habitats to compensate habitat loss.

It was not until the shift from legal framework to more informal adaptive governance at the national-level and regional-level policies that successional dynamics at false heath fritillary habitats was acknowledged as the main conservation challenge of the species, and it was addressed by the regional-level authorities in the form of habitat quality assessments and habitat restoration plans for degraded sites. These activities were supported by 
regional prioritization meetings of endangered species, an outcome of a National Species Conservation Action Plan prepared in 2010-2011 (Ministry of the Environment 2016, SYKE 2017). The meetings provided guidance and commitment from national-level actors, such as SYKE, Ministry of the Environment, Finnish Forestry Service, and taxon-specific experts of the national endangered species working groups, into regional-level conservation planning. For false heath fritillary conservation, the meetings provided support for the prioritization of ELY centers' conservation tasks and committed key nationallevel actors to the regional execution of false heath fritillary conservation activities on state-owned land. However, the agreements as such did not provide resources for the ELY centers for carrying out the prioritized tasks.

The case of the false heath fritillary demonstrates that conservation programs may lack tools, processes, and formal policies for tackling habitat dynamics even if they have been designed to conserve species that live in dynamic landscapes. This can lead to a functional misfit, if conservation institutions are optimized for tackling different threats than what are the primary causes of endangerment for the species in question. We suggest the following questions for assessing the level of acknowledgment of habitat dynamics in conservation institutions:

1. Are habitat dynamics acknowledged as a key conservation challenge of the managed system both in the formal and informal conservation policies?

2. Does such acknowledgment extend to all relevant spatial scales of policy making, e.g., governmental level, regional level, and local level?

3. Has such acknowledgment led to defined targets and task prioritization that help with responding to habitat dynamics?

4. Has such acknowledgment led to the provision of operational tools and resource allocation that help with responding to habitat dynamics?

If formal conservation policies or informal policies at the governmental level do not acknowledge habitat dynamics as a conservation challenge, regional- or local-level actors may have restricted opportunities to tackle habitat dynamics because of the task prioritizations and resource allocations defined in the governmental-level decision making. Therefore, attaining high institutional fit may require that acknowledgment of habitat dynamics is extended to those levels and forms of governance that control local-level task prioritization and resources (Folke et al. 2005, Vatn and Vedeld 2012). Operational tools and resources for tackling habitat dynamics could be invoked if the challenge of habitat dynamics was acknowledged in the documented causes of threat, threat factors (Rassi et al. 2010), threatening processes (Hoffmann et al. 2008), or recommended conservation actions (Rodrigues et al. 2006) in the respective Red List documentation or in the objectives of recovery of a species-specific recovery plan (McDonald et al. 2015). Alternatively, informal governmentallevel policies, such as information sharing and decision-making practices that are not defined in the legislation, could be revised so that such targets, priorities, operational tools, and resources are ensured that enable the management of habitat dynamics. A more thorough solution could require a reform of conservation policies to allow adaptive management of complex systems (Green et al. 2015).

Monitoring of and responding to changes in the habitat network The respondents did not have clear and unified views on how proactively ELY centers should collect information on the false heath fritillary and on changes in the numbers, sizes, qualities, and locations of its habitat patches to assess the adequacy of its habitat network, because the legislation did not explicitly pose responsibilities on this matter to any organization. Regional authorities responsible for heath fritillary conservation, however, collected information of false heath fritillary sightings and the locations of false heath fritillary habitats with the help of contractors and volunteers, such as citizen experts from the local Entomological Society. In Pirkanmaa, where the conservation history of the species was decades long, regional authorities surveyed the meadow network with the help of contractors once a decade. The surveys included a qualitative classification of habitat sites according to the urgency of their restoration. Surveys were followed by habitat restoration programs that included contacts to habitat landowners and making habitat restoration plans with cooperative landowners. Restoration programs moved annually from one subregion to another to gain synergies from cooperating with multiple landowners at the same time per subregion; this enabled information-sharing meetings and the change of expertise between involved landowners.

The decadal rhythm of habitat network surveys in Pirkanmaa was driven by resource availability in relation to the extent of the habitat network to be maintained. Based on existing knowledge of habitat succession at false heath fritillary meadows (Intke 2003, Fabritius and McBride 2017), the tempo of habitat dynamics at false heath fritillary habitats was, however, often faster than this. Consequently, reports of habitat network surveys indicated that large proportions of habitats had already been destroyed in the process of habitat succession by the times of the surveys (Kekkonen and Rönkä 2009). This generated a temporal misfit for false heath fritillary conservation because information lags prevented the timing of habitat maintenance activities within such temporal windows of opportunity (Folke et al. 2007) that would have prevented local extinctions of false heath fritillary populations at degraded habitats. The spatiotemporal aggregation of the resulting habitat restoration programs (Fig. 1) was another potential source of spatiotemporal misfit. Synchronized restoration of nearby habitats was likely to generate a spatiotemporal pattern in which habitats located close to each other had synchronized successional dynamics. According to past studies of dynamic habitats, such spatial aggregation of habitat dynamics can either increase or decrease species' metapopulation sizes in dynamic landscapes, depending on their life history traits (Johst and Drechsler 2003, Hinsch and Poethke 2007, Elkin and Possingham 2008). It was not known which one was the case for the false heath fritillary.

Effective management of habitat network dynamics benefits from the collection of spatial and temporal resilience assessment data (Allen et al. 2016) that can be used to build knowledge on the system's dynamics and critical thresholds. This knowledge can then be used to determine the right triggers and scales of action for conservation management in the case of perturbations and 
gradual system changes. We suggest the following questions for assessing the fit of monitoring and responding to changes in dynamic habitat networks:

Fig. 1. Annual funding by the Ministry of the Environment to the Pirkanmaa ELY center for false heath fritillary conservation in 2005-2014. Dashed lines depict the lower and upper bounds of estimated annual funds for the years 2005-2010, for which exact records per species were not available. The increased funding in 2011-2014 reflects a large-scale habitat restoration program that followed the 2009 habitat network survey and consisted of site maintenance, landowner contacts, and the development of new, experimental habitat maintenance methods. ELY center, Centre of the Economic Development, Transport and the Environment.

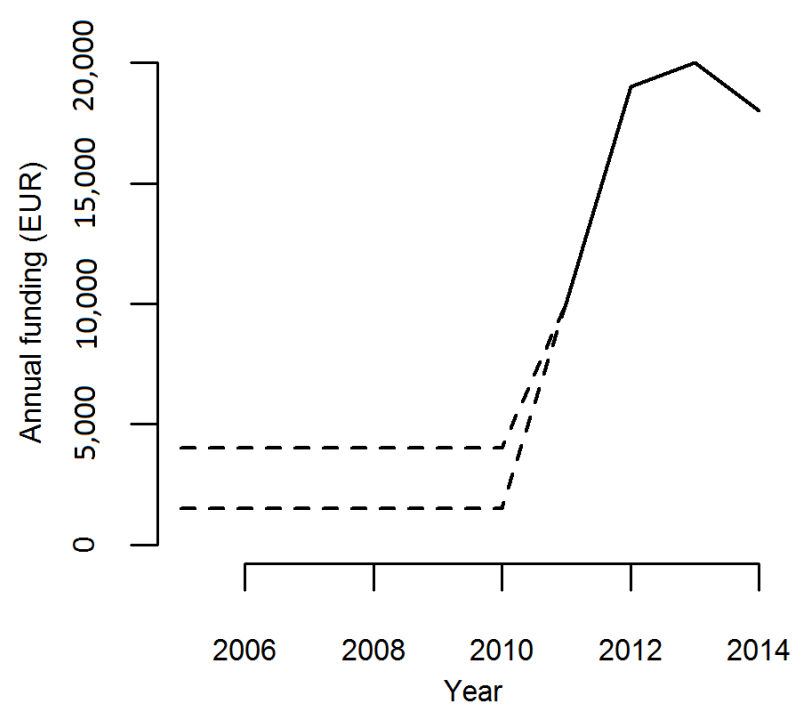

1. Do conservation managers collect information on habitat network dynamics?

2. Is the average time interval of receiving or collecting such data shorter than the expected lifetime of most temporary habitats?

3. Is information of temporal habitat dynamics collected using such standardized measures that ensure the comparability of data across years and surveyors?

4. Do conservation managers receive information from landowners or volunteers on changes in landownership, land use type, or destruction of habitats?

5. Is there a systematic method for searching for emerging habitats?

6. Are conservation managers able to anticipate changes in the habitat network based on site maintenance histories and/or modeled temporal dynamics of habitats?

Effective management of habitat network dynamics requires timely information on changes in the habitat patch network so that conservation management plans can be iterated based on upto-date data on the system state (Green et al. 2015). Such information may be collected via regular patch network surveys that are organized within time intervals that leave a window of opportunity to carry out maintenance activities before local population extinctions take place at degrading habitat patches. The timeliness of available information could be further increased by setting up mechanisms that enable landowners to report changes concerning habitat patches located at their properties, such as habitat maintenance activities, habitat destruction, changes in landownership, and changes in land use plans at the property (Pocewicz et al. 2008, Dayer et al. 2016). Additionally, depending on the habitat type in question, the search of new, emerged habitat patches could be carried out either by conducting regular field surveys or by studying land use records that may reveal probable locations of habitat emergence.

The use of standardized measures enables the accumulation of such data on patch and patch network dynamics that is comparable across years and surveyors and that can thus be used for predicting system dynamics, thresholds, and future development. For instance, if repeated standardized measurements of habitat sizes and qualities can be complemented with systematic records of habitat maintenance and land use histories, predictive models can be developed for estimating how management interventions impact habitat qualities and succession (Pöyry et al. 2006, Taylor and Morecroft 2009). Such predictive models could be used to estimate the annual need for maintenance resources for the system and to define suitable time intervals for future habitat network surveys.

\section{Management of resources for fluctuating resource needs}

In false heath fritillary conservation, both resource needs and resource availability fluctuated in time. Annual resource needs at the three ELY centers depended on which activities related to the false heath fritillary, i.e., species monitoring, habitat network surveys, or restoration programs, were planned for the given year and how many habitat sites were planned to be maintained or restored using the resources of the ELY centers. Although no earmarked funding existed for these activities, the budget of the Ministry of the Environment contained two clauses that could be used to cover costs of activities related to the false heath fritillary. Resources available in the Ministry of the Environment for the two clauses fluctuated annually depending on the state budget and on temporally fluctuating priorities, such as the execution of large-scale conservation programs or updating the Finnish Red List of Endangered Species, which usually took place for 3 years every 10 years. The annual funding received by the ELY centers was therefore often surprisingly small, sometimes even less than half of the sum applied for false heath fritillary conservation. Consequently, ELY centers had to prioritize different species in different years to get adequate funding for executing speciesspecific projects.

Access to maintenance funding for false heath fritillary habitats also varied according to the type of habitat ownership, farmer status, landowner's ability to carry out habitat maintenance independently, and demarcation status of the habitat (Fig. 2). The 5-year or 10-year agri-environmental support contracts provided an important source of funding for the maintenance of false heath fritillary habitats by landowners, given the proportionally large amounts of funding available in the agri-environmental support and the long term of the support contracts. However, this European Union-based source of funding was only available for 
farmers entitled to farming support. The utilization of agrienvironmental schemes for the maintenance of false heath fritillary habitats also depended on whether habitats to be maintained were located on a property that met the conditions of the support and whether habitats were large enough so that the area-based agri-environmental support covered habitat maintenance costs. The application process also required high landowner motivation and time investment from the personnel of the ELY center, which limited the usage of this source of funding. The unpredictability and inflexibility of available maintenance funding therefore caused a spatiotemporal misfit in the management of habitat network dynamics for false heath fritillary conservation because it limited conservation managers' possibilities to plan and steer resource allocation.

Fig. 2. Sources for habitat maintenance funding for a false heath fritillary habitat depending on the type of landowner, demarcation status and farmer status of the habitat, and the landowner's ability to carry out habitat maintenance independently. ELY center, Centre of the Economic Development, Transport and the Environment.

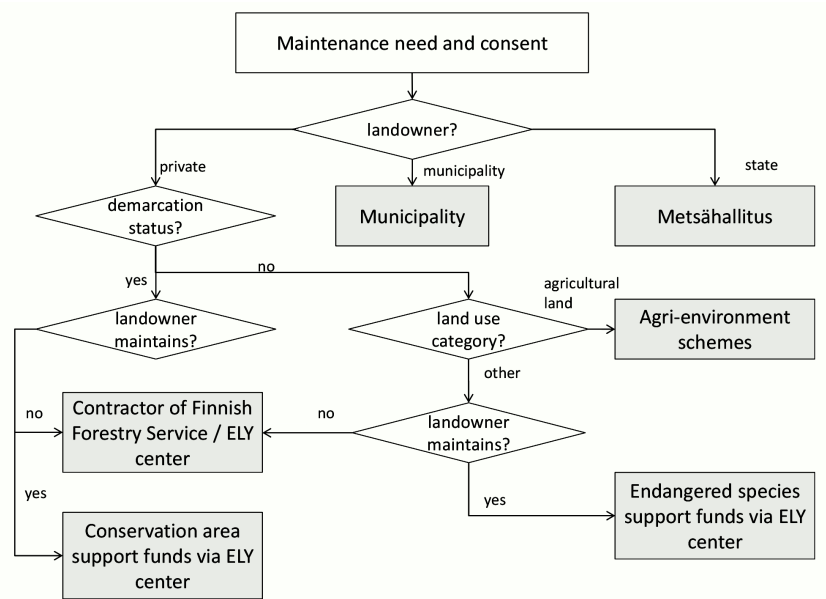

Effective management of habitat network dynamics would require that the resources available for habitat maintenance can be allocated across time and space according to what minimizes habitat discontinuities for the species of interest. We suggest the following questions for assessing the fit of managing resources for fluctuating resource needs:

1. Do conservation managers have data on how spatial or temporal fluctuations of the habitat network affect the species of interest?

2. Do conservation managers allocate maintenance resources according to long-term spatial conservation plans?

3. Can conservation managers buffer and distribute management resources across years to maximize the effectiveness of resource use?

4. Can conservation managers allocate maintenance resources flexibly in terms of location to maximize the effectiveness of resource use?
Being able to allocate maintenance resources across time and space for the species of interest requires an understanding of how the species' metapopulation dynamics are affected by different spatiotemporal patterns of habitat availability. Without detailed studies of the managed system, such patterns are not self-evident. For instance, spatial aggregation of disturbances may or may not alleviate the detrimental effects of local habitat destruction to disturbance-dependent species depending on species-specific traits (Johst and Drechsler 2003, Hinsch and Poethke 2007, Elkin and Possingham 2008), and intensive maintenance of a smaller habitat network may or may not be beneficial in comparison to creating new habitats (Ross et al. 2008). Ideally, multiple realistic scenarios of habitat network dynamics could be developed for the landscapes being managed, and the metapopulation dynamics of the species of interest could be modeled using these alternative scenarios. As in many cases, resource limitation may prevent the development or application of such predictive tools, but existing models that have been developed for species of similar life history traits could be used as guidance for determining effective spatiotemporal management strategies. In the absence of any estimates of a species' metapopulation responses to landscape dynamics, management could aim at maximizing patch lifetimes while minimizing changes in habitat numbers and locations whenever possible because these strategies have generally been shown to maintain higher population sizes than rapidly changing habitat networks (Johst et al. 2011, Van Teeffelen et al. 2012).

At the same time, conservation management on private land takes place in the reality of multiple constraints, such as resource shortages and the reliance on landowner cooperation (Opdam et al. 2008), which may prevent following the most effective management strategies. For such cases, there is a need for practical decision-making rules or tools that enable planning of the timing and placement of habitat maintenance activities given such constraints or under uncertainty.

Conservation managers' ability to allocate resources across time and space could be improved if maintenance budgets were flexible in time, and managers could decide whether to save for following years or spend the full budget (see, e.g., Drechsler et al. 2007). This would enable managers to utilize more resources during years of need for larger amounts of maintenance funding or to flatten the fluctuations of available conservation funds across years. Improving conservation managers' ability to allocate maintenance resources flexibly in terms of location would require either a general-level allocation of funds for the maintenance of the habitat network, which would reduce managers' dependency on applying for alternative sources of funding, or, in the case of early successional habitats, more flexible rules for the use of agrienvironmental support. Annual funding allocations should also be handled at such scale of governance that allows flexible determination of the right scale of action (Green et al. 2015), for instance reallocation of resources between management regions in the case of larger perturbations at particular regions.

\section{Scaling of activities through flexible collaborations}

In the three ELY centers, resource shortages restricted personnel resources that could be spent on false heath fritillary conservation, and most resources went into handling bureaucratic matters or being in contact with landowners. Therefore, false heath fritillary distribution and habitat network surveys, as well as habitat 
Table 1. Numbers of endangered species in the Finnish Red List of Endangered Species 2010 (Rassi et al. 2010) in all taxa (left), in Lepidoptera (middle), and in vascular plants (right) for which the major cause of endangerment is habitat suffocation (threat code $\mathrm{N}$ ), grouped according to their endangerment status: critically endangered (CR), endangered (EN), and vulnerable (VU). The table lists the numbers of species threatened by habitat overgrowth in the respective taxa that are classified as species under strict protection and would, based on the opinions of two taxon-specific experts, also require species-specific conservation plans like the false heath fritillary.

\begin{tabular}{|c|c|c|c|c|c|c|c|c|c|c|c|c|}
\hline & \multicolumn{4}{|c|}{ All taxa } & \multicolumn{4}{|c|}{ Lepidoptera } & \multicolumn{4}{|c|}{ Vascular plants } \\
\hline & $\mathrm{CR}$ & EN & $\mathrm{VU}$ & Total & $\mathrm{CR}$ & EN & $\mathrm{VU}$ & Total & $\mathrm{CR}$ & EN & $\mathrm{VU}$ & Total \\
\hline $\begin{array}{l}\text { Total number of endangered species } \\
\text { threatened by habitat overgrowth }\end{array}$ & 107 & 388 & 389 & 884 & 30 & 151 & 92 & 273 & 9 & 47 & 37 & 93 \\
\hline $\begin{array}{l}\text { Of which, species under strict protection } \\
\text { Of which, species in need of species- } \\
\text { specific conservation plans (estimated by } \\
\text { expert 1) }\end{array}$ & 54 & 192 & 25 & 271 & $\begin{array}{c}17 \\
6\end{array}$ & $\begin{array}{l}74 \\
21\end{array}$ & $\begin{array}{l}1 \\
1\end{array}$ & $\begin{array}{l}92 \\
28\end{array}$ & 5 & 29 & 2 & 36 \\
\hline $\begin{array}{l}\text { Of which, species in need of species- } \\
\text { specific conservation plans (estimated by } \\
\text { expert } 2 \text { ) }\end{array}$ & & & & & & & & & 2 & 16 & 1 & 19 \\
\hline
\end{tabular}

maintenance planning and information sharing to landowners, were handed to external contractors or volunteers. The amount of contracted work varied annually depending on the amount of funding available, but also according to the landownership of habitats to be maintained: Landowners varied from active farmers to retired farmers and to people living or working in urban areas, and habitats were either maintained by landowners themselves or needed to be maintained by contractors.

Collaboration, when it was needed, had to be scaled up fast: Information on funding allocations by the Ministry of the Environment was usually available in February, and spring activities at maintained sites had to be carried out before the start of the growth season in April or May. Additionally, ELY centers needed experienced contractors that could carry out the needed tasks independently. This did not cause major problems in Pirkanmaa, where there was no shortage of experienced contractors and where plans and contracts could be scaled fast according to the amount of available funding based on known best practices from past collaborations. In the other two administrative regions, which had fewer actors in the civil society, experienced contractors did not exist, and the short-term nature of annually contracted work complicated the development of expertise among the few potential collaborators.

The short-term allocation of maintenance resources caused a risk of temporal misfit in the execution of maintenance activities because the short time frames in which projects had to be established could have outpaced the tempo of finding contractors. This, in turn, could have led to deficiencies in the execution of planned maintenance activities. Such misfit could be alleviated via the buildup of collaboration networks that enable fast scaling of activities or by widening the time frames of resource availability to conservation managers. We suggest the following questions for assessing the fit of scaling activities through flexible collaborations:

1. Do conservation managers have access to an adequate supply of experienced in-house personnel or external contractors that can be involved in habitat maintenance activities when needed?
2. Is the time frame available from funding allocations to the preferred time of execution of maintenance activities adequate for activating a scalable workforce?

Having the possibility to distribute maintenance resources flexibly over multiple years would enable longer term planning of resource use and longer planning horizons for scaling up operations. Thus, it would also enable the creation of long-term management contracts, commitment, and capacity building with local contractors.

\section{The case of the false heath fritillary in relation to other species} According to the estimates of two taxon-specific experts, Finland has at least 19 and 28 endangered species in the studied taxa of vascular plants and Lepidoptera, respectively, that are similar to the false heath fritillary with respect to their status as endangered species (CR, EN, or VU), status as species of strict protection, main cause of endangerment, and estimated need for speciesspecific conservation plans (Table 1). These estimates correspond to $10.2 \%$ and $20.4 \%$ of all endangered species in the respective taxa that are threatened by successional habitat dynamics. As these numbers estimate the numbers and fractions of species for which conservation is likely to raise similar challenges and potential institutional misfits as those identified for the false heath fritillary, the implications and recommendations we identified are of general application and importance.

\section{CONCLUSION}

The four institutional arrangements identified in our case study, i.e., acknowledgment of habitat dynamics, monitoring of and responding to changes in the habitat network, managing resources for fluctuating resource needs, and scaling of activities through flexible collaborations, stress the importance of institutional flexibility and adaptive governance in the conservation of dynamic habitat networks. High performance in the conservation of dynamic systems requires the ability to respond fast to potentially emerging habitat discontinuities that could be detrimental to species being conserved. Our findings thus agree with many previous findings on the effective management of social-ecological systems, which highlight the importance of environmental monitoring (Cox 2012), adaptive capacity (Folke et al. 2007, Garmestani et al. 2013, Allen et al. 2016), cross-scale 
interactions (Hansen 2014), and the utilization of landowners' knowledge (Olsson et al. 2007, Green et al. 2015) in the attainment of high institutional fit in these contexts.

As demonstrated by the expert estimates on the generalizability of our case study, habitat dynamics may be an overlooked conservation challenge that calls for new kinds of institutional arrangements that can maintain habitat availability for species living in dynamic landscapes. In the era of climate change, such flexibility may prove beneficial for a larger extent of species than those living in early successional habitats. In the face of potentially large-scale perturbations, such as possible extreme climate events, conservation managers could aim at increasing, not only maintaining, system resilience by increasing the heterogeneity and connectivity of habitat patch networks and facilitating their spatial extension toward the direction of predicted suitable climates of the future. Transformation from traditional conservation management, which is based on rigid rules and management of system pieces as independent units (Allen et al. 2016), is, however, likely to require legal reform before the adaptive management of complex systems would be fully enabled in conservation institutions (Green et al. 2015).

\section{Responses to this article can be read online at: http://www.ecologyandsociety.org/issues/responses. $\mathrm{php} / 9203$}

\section{Acknowledgments:}

We thank Bettina Sommarström for collecting data and expert estimates on the generalizability of our case study, the interviewees for their time and participation, the experts who estimated the generalizability of our study case, and Jenny Hodgson and Mikko Kuussaari for their comments on a previous version of the manuscript.

\section{LITERATURE CITED}

Adam, B. 2000. The temporal gaze: the challenge for social theory in the context of GM food. British Journal of Sociology 51:125-142.

Allen, C. R., D. G. Angeler, G. S. Cumming, C. Folke, D. Twidwell, and D. R. Uden. 2016. Quantifying spatial resilience. Journal of Applied Ecology 53:625-635. http://dx.doi.org/10.1111/1365-2664.12634

Arponen, A., R. K. Heikkinen, R. Paloniemi, J. Pöyry, J. Similä, and M. Kuussaari. 2013. Improving conservation planning for semi-natural grasslands: integrating connectivity into agrienvironment schemes. Biological Conservation 160:234-241. http://dx.doi.org/10.1016/j.biocon.2013.01.018

Askins, R. A. 2001. Sustaining biological diversity in early successional communities: the challenge of managing unpopular habitats. Wildlife Society Bulletin 29:407-412.

Bengtsson, J., P. Angelstam, T. Elmqvist, U. Emanuelsson, C. Folke, M. Ihse, F. Moberg, and M. Nyström. 2003. Reserves, resilience and dynamic landscapes. AMBIO: A Journal of the Human Environment 32:389-396. http://dx.doi.org/10.1579/0044$\underline{-7447-32.6 .389}$
Boughton, D., and U. Malvadkar. 2002. Extinction risk in successional landscapes subject to catastrophic disturbances. Conservation Ecology 6(2):2. http://dx.doi.org/10.5751/ES-00426-060202

Bulman, C. R., R. J. Wilson, A. R. Holt, L. G. Bravo, R. I. Early, M. S. Warren, and C. D. Thomas. 2007. Minimum viable metapopulation size, extinction debt, and the conservation of a declining species. Ecological Applications 17:1460-1473. http://dx. doi.org/10.1890/06-1032.1

Cabeza, M. 2003. Habitat loss and connectivity of reserve networks in probability approaches to reserve design. Ecology Letters 6:665-672. http://dx.doi.org/10.1046/j.1461-0248.2003.00475. $\underline{x}$

Cash, D. W., W. Adger, F. Berkes, P. Garden, L. Lebel, P. Olsson, L. Pritchard, and O. Young. 2006. Scale and cross-scale dynamics: governance and information in a multilevel world. Ecology and Society 11(2):8. http://dx.doi.org/10.5751/es-01759-110208

Centre for Economic Development, Transport and the Environment. 2016. Centre for Economic Development, Transport and the Environment. Centre for Economic Development, Transport and the Environment, Helsinki, Finland.[online] URL: http://www.ely-keskus.fi/en/web/ely-en/

Cox, M. 2012. Diagnosing institutional fit: a formal perspective. Ecology and Society 17(4):54. http://dx.doi.org/10.5751/ es-05173-170454

Dayer, A. A., R. C. Stedman, S. B. Allred, K. V. Rosenberg, and A. K. Fuller. 2016. Understanding landowner intentions to create early successional forest habitat in the northeastern United States. Wildlife Society Bulletin 40:59-68. http://dx.doi.org/10.1002/ wsb. 613

Dettmers, R. 2003. Status and conservation of shrubland birds in the northeastern US. Forest Ecology and Management 185:81-93. http://dx.doi.org/10.1016/S0378-1127(03)00248-2

Drechsler, M., F. Wätzold, K. Johst, H. Bergmann, and J. Settele. 2007. A model-based approach for designing cost-effective compensation payments for conservation of endangered species in real landscapes. Biological Conservation 140:174-186. http://dx. doi.org/10.1016/i.biocon.2007.08.013

Ekstrom, J. A., and O. R. Young. 2009. Evaluating functional fit between a set of institutions and an ecosystem. Ecology and Society 14(2):16. http://dx.doi.org/10.5751/es-02930-140216

Elkin, C. M., and H. Possingham. 2008. The role of landscapedependent disturbance and dispersal in metapopulation persistence. American Naturalist 172:563-575. http://dx.doi. org/10.1086/590962

Enck, J., and M. Odato. 2008. Public attitudes and affective beliefs about early- and late-successional stages of the Great Northern Forest. Journal of Forestry 106:388-395.

European Commission. 2005. Agri-environment measures. Overview on general principles, types of measures, and application. Directorate General for Agriculture and Rural Development, European Commission, Brussels, Belgium. [online] URL: http:// ec.europa.eu/agriculture/publi/reports/agrienv/rep en.pdf

Fabritius, H., and M. McBride. 2017. Modelling habitat persistence and impacts of management on the habitats of an 
endangered butterfly. Insect Conservation and Diversity 10:200-210. http://dx.doi.org/10.1111/icad.12218

Farrell, K. N., and A. Thiel. 2013. Nudging evolution? Ecology and Society 18(4):47. http://dx.doi.org/10.5751/ES-05945-180447

Finnish Environment Institute (SYKE). 2017. Uhanalaisten lajien suojelun toimintaohjelma. SYKE, Helsinki, Finland. [online] URL: http://www.ymparisto.fi/fi-FI/Luonto/Lajit/Lajiensuojelutyo/ Uhanalaisten lajien suojelun toimintaohjelma

Folke, C. 2006. Resilience: the emergence of a perspective for social-ecological systems analyses. Global Environmental Change 16:253-267. http://dx.doi.org/10.1016/j.gloenvcha.2006.04.002

Folke, C., T. Hahn, P. Olsson, and J. Norberg. 2005. Adaptive governance of social-ecological systems. Annual Review Environment and Resources 30:441-473. http://dx.doi.org/10.1146/ annurev.energy.30.050504.144511

Folke, C., L. Pritchard, F. Berkes, J. Colding, and U. Svedin. 2007. The problem of fit between ecosystems and institutions: ten years later. Ecology and Society 12(1):30. http://dx.doi.org/10.5751/ ES-02064-120130

Garmestani, A. S., C. R. Allen, and M. H. Benson. 2013. Can law foster social-ecological resilience? Ecology and Society 18(2):37. http://dx.doi.org/10.5751/es-05927-180237

Green, O. O., A. S. Garmestani, C. R. Allen, L. H. Gunderson, J. B. Ruhl, C. A. Arnold, N. A. J. Graham, B. Cosens, D. G. Angeler, B. C. Chaffin, and C. S. Holling. 2015. Barriers and bridges to the integration of social-ecological resilience and law. Frontiers in Ecology and the Environment 13:332-337. http://dx. doi.org/10.1890/140294

Halada, L., D. Evans, C. Romão, and J.-E. Petersen. 2011. Which habitats of European importance depend on agricultural practices? Biodiversity and Conservation 20:2365-2378. http://dx. doi.org/10.1007/s10531-011-9989-Z

Haller, T., G. Fokou, G. Mbeyale, and P. Meroka. 2013. How fit turns into misfit and back: institutional transformations of pastoral commons in African floodplains. Ecology and Society 18 (1):34. http://dx.doi.org/10.5751/es-05510-180134

Hansen, W. D. 2014. Generalizable principles for ecosystem stewardship-based management of social-ecological systems: lessons learned from Alaska. Ecology and Society 19(4):13. http:// dx.doi.org/10.5751/es-06907-190413

Hanski, I. 1994. A practical model of metapopulation dynamics. Journal of Animal Ecology 63:151-162. http://dx.doi. org/10.2307/5591

Hanski, I. 1999. Habitat connectivity, habitat continuity, and metapopulations in dynamic landscapes. OIKOS 87:209-219. http://dx.doi.org/10.2307/3546736

Hanski, I., and O. Ovaskainen. 2000. The metapopulation capacity of a fragmented landscape. Nature 404:755-758. http:// dx.doi.org/10.1038/35008063

Hiedanpää, J. 2013. Institutional misfits: law and habits in Finnish wolf policy. Ecology and Society 18(1):24. http://dx.doi. org/10.5751/es-05302-180124
Hinsch, M., and H.-J. Poethke. 2007. Consequences of cyclic vegetation management for arthropod survival: simulation experiments. Basic and Applied Ecology 8:321-331. http://dx.doi. org/10.1016/j.baae.2006.09.011

Hoffmann, M., T. M. Brooks, G. A. B. da Fonseca, C. Gascon, A. F. A. Hawkins, R. E. James, P. Langhammer, R. A. Mittermeier, J. D. Pilgrim, A. S. L. Rodrigues, and J. M. C. Silva. 2008. Conservation planning and the IUCN Red List. Endangered Species Research 6:113-125. http://dx.doi.org/10.3354/esr00087

Hukkinen, J. I. 2012. Fit in the body: matching embodied cognition with social-ecological systems. Ecology and Society 17 (4):30. http://dx.doi.org/10.5751/es-05241-170430

Intke, S. 2003. Niittyjen hoitotoimenpiteet uhanalaisen tummaverkkoperhosen (Melitaea diamina) suojelussa. Thesis. University of Jyväskylä, Jyväskylä, Finland.

Johst, K., and M. Drechsler. 2003. Are spatially correlated or uncorrelated disturbance regimes better for the survival of species? OIKOS 103:449-456. http://dx.doi.org/10.1034/ j.1600-0706.2003.12770.x

Johst, K., M. Drechsler, A. J. A. van Teeffelen, F. Hartig, C. C. Vos, S. Wissel, F. Wätzold, and P. Opdam. 2011. Biodiversity conservation in dynamic landscapes: trade-offs between number, connectivity and turnover of habitat patches. Journal of Applied Ecology 48:1227-1235. http://dx.doi.org/10.1111/j.1365-2664.2011.02015. $\underline{x}$

Jokinen, A. 2006. Standardization and entrainment in forest management. Pages 198-217 in Y. Haila and C. Dyke, editors. How nature speaks: the dynamics of the human ecological condition. Duke University Press, Durham, North Carolina, USA.

Keeley, J. E., and C. J. Fotheringham. 2001. History and management of crown-fire ecosystems: a summary and response. Conservation Biology 15:1561-1567. http://dx.doi.org/10.1046/ j.1523-1739.2001.t01-1-00186.X

Kekkonen, M., and K. Rönkä. 2009. Tummaverkkoperhoskartoitus Pirkanmaalla 2009. University of Helsinki, Helsinki, Finland.

Kleijn, D., R. A. Baquero, Y. Clough, M. Díaz, J. De Esteban, F. Fernández, D. Gabriel, F. Herzog, A. Holzschuh, R. Jöhl, E. Knop, A. Kruess, E. J. P. Marshall, I. Steffan-Dewenter, T. Tscharntke, J. Verhulst, T. M. West, and J. L. Yela. 2006. Mixed biodiversity benefits of agri-environment schemes in five European countries. Ecology Letters 9:243-254. http://dx.doi. org/10.1111/j.1461-0248.2005.00869.x

Lebel, L., J. M. Anderies, B. Campbell, C. Folke, S. HatfieldDodds, T. P. Hughes, and J. Wilson. 2006. Governance and the capacity to manage resilience in regional social-ecological systems. Ecology and Society 11(1):19. http://dx.doi.org/10.5751/ es-01606-110119

Lebel, L., E. Nikitina, C. Pahl-Wostl, and C. Knieper. 2013. Institutional fit and river basin governance: a new approach using multiple composite measures. Ecology and Society 18(1):1. http:// dx.doi.org/10.5751/es-05097-180101

Liinalaakso, O. 2000. Tummaverkkoperhosniittyjen maankäytön historiaa ja nykypäivää. Pages 7-13 in J. Heliölä, O.-P. Liinalaakso, R. Martikainen, and T. Schultz T, editors. 
Tummaverkkoperhonen Pirkanmaalla. Pirkanmaan ympäristökeskus, Tampere, Finland.

Long, J. N. 2009. Emulating natural disturbance regimes as a basis for forest management: a North American view. Forest Ecology and Management 257:1868-1873. http://dx.doi.org/10.1016/j. foreco.2008.12.019

Lourival, R., M. Drechsler, M. E. Watts, E. T. Game, and H. P. Possingham. 2011. Planning for reserve adequacy in dynamic landscapes: maximizing future representation of vegetation communities under flood disturbance in the Pantanal wetland. Diversity and Distributions 17:297-310. http://dx.doi.org/10.1111/ j.1472-4642.2010.00722.x

Lytle, D. A., and N. LeRoy Poff. 2004. Adaptation to natural flow regimes. Trends in Ecology \& Evolution 19:94-100. http://dx.doi. org/10.1016/j.tree.2003.10.002

McDonald, J. A., J. Carwardine, L. N. Joseph, C. J. Klein, T. M. Rout, J. E. M. Watson, S. T. Garnett, M. A. McCarthy, and H. P. Possingham. 2015. Improving policy efficiency and effectiveness to save more species: a case study of the megadiverse country Australia. Biological Conservation 182:102-108. http://dx.doi. org/10.1016/j.biocon.2014.11.030

Ministry of the Environment. 1996. Nature Conservation Act 1096/1996 English. Sect. 47. Finlex Data Bank, Finnish Ministry of Justice, Helsinki, Finland. [online] URL: http://www.finlex.fi/ en/laki/kaannokset/1996/en19961096

Ministry of the Environment. 1997. Nature Conservation Decree 160/1997 English. Finlex Data Bank, Finnish Ministry of Justice, Helsinki, Finland. [online] URL: http://finlex.fi/en/laki/ kaannokset/1997/en19970160

Ministry of the Environment. 2015. Finland's environmental administration. Ministry of the Environment, Helsinki, Finland. [online] URL: http://www.ymparisto.fi/en-US/Finlands environmental administration $\% 2824294 \% 29$

Ministry of the Environment. 2016. National action plan for species protection. Ministry of the Environment, Helsinki, Finland. [online] URL: http://www.ym.fi/en-US/Nature/Biodiversity/ Nature conservation programmes/Action programmes

Moilanen, A., J. Laitila, T. Vaahtoranta, L. V. Dicks, and W. J. Sutherland. 2014. Structured analysis of conservation strategies applied to temporary conservation. Biological Conservation 170:188-197. http://dx.doi.org/10.1016/j.biocon.2014.01.001

Mortelliti, A., G. Amori, and L. Boitani. 2010. The role of habitat quality in fragmented landscapes: a conceptual overview and prospectus for future research. Oecologia 163:535-547. http://dx. doi.org/10.1007/s00442-010-1623-3

Moss, T. 2012. Spatial fit, from panacea to practice: implementing the EU Water Framework Directive. Ecology and Society 17(3):2. http://dx.doi.org/10.5751/es-04821-170302

Munck af Rosenschöld, J., N. Honkela, and J. I. Hukkinen. 2014. Addressing the temporal fit of institutions: the regulation of endocrine-disrupting chemicals in Europe. Ecology and Society 19(4):30. http://dx.doi.org/10.5751/es-07033-190430

Olsson, P., C. Folke, V. Galaz, T. Hahn, and L. Schultz. 2007. Enhancing the fit through adaptive co-management: creating and maintaining bridging functions for matching scales in the Kristianstads Vattenrike Biosphere Reserve, Sweden. Ecology and Society 12(1):28. http://dx.doi.org/10.5751/es-01976-120128

Opdam, P., R. Pouwels, S. van Rooij, E. Steingröver, and C. C. Vos. 2008. Setting biodiversity targets in participatory regional planning: introducing ecoprofiles. Ecology and Society 13(1):20. http://dx.doi.org/10.5751/es-02438-130120

Ostrom, E. 2007. A diagnostic approach for going beyond panaceas. Proceedings of the National Academy of Sciences of the United States of America 104(39):15181-15187. http://dx.doi. org/10.1073/pnas.0702288104

Paavola, J., A. Gouldson, and T. Kluvánková-Oravská. 2009. Interplay of actors, scales, frameworks and regimes in the governance of biodiversity. Environmental Policy and Governance 19(3):148-158. http://dx.doi.org/10.1002/eet.505

Pérez-Nordtvedt, L., G. T. Payne, J. C. Short, and B. L. Kedia. 2008. An entrainment-based model of temporal organizational fit, misfit, and performance. Organization Science 19(5):785-801. http://dx.doi.org/10.1287/orsc. 1070.0330

Pocewicz, A., M. Nielsen-Pincus, C. S. Goldberg, M. H. Johnson, P. Morgan, J. E. Force, L. P. Waits, and L. Vierling. 2008. Predicting land use change: comparison of models based on landowner surveys and historical land cover trends. Landscape Ecology 23:195-210. http://dx.doi.org/10.1007/s10980-007-9159-6

Pöyry, J., M. Luoto, J. Paukkunen, J. Pykälä, K. Raatikainen, and M. Kuussaari. 2006. Different responses of plants and herbivore insects to a gradient of vegetation height: an indicator of the vertebrate grazing intensity and successional age. OIKOS 115:401-412. http://dx.doi.org/10.1111/j.2006.0030-1299.15126. $\underline{\mathrm{X}}$

Radchuk, V., K. Johst, J. Groeneveld, C. Turlure, V. Grimm, and N. Schtickzelle. 2014. Appropriate resolution in time and model structure for population viability analysis: insights from a butterfly metapopulation. Biological Conservation 169:345-354. http://dx.doi.org/10.1016/j.biocon.2013.12.004

Rassi, P., E. Hyvärinen, A. Juslén, and I. Mannerkoski, editors. 2010. Suomen lajien uhanalaisuus - Punainen kirja 2010. Ympäristöministeriö \& Suomen ympäristökeskus, Helsinki, Finland.

Richards, S. A., H. P. Possingham, and J. Tizard. 1999. Optimal fire management for maintaining community diversity. Ecological Applications 9:880-892. http://dx.doi.org/10.1890/1051-0761 (1999)009[0880:OFMFMC]2.0.CO;2

Rodrigues, A. S. L., J. D. Pilgrim, J. F. Lamoreux, M. Hoffmann, and T. M. Brooks. 2006. The value of the IUCN Red List for conservation. Trends in Ecology \& Evolution 21:71-76. http://dx. doi.org/10.1016/j.tree.2005.10.010

Ross, J. V., D. J. Sirl, P. K. Pollett, and H. P. Possingham. 2008. Metapopulation persistence in a dynamic landscape: more habitat or better stewardship? Ecological Applications 18:590-598. http:// dx.doi.org/10.1890/07-1094.1

Schouten, M., P. Opdam, N. Polman, and E. Westerhof. 2013. Resilience-based governance in rural landscapes: experiments with agri-environment schemes using a spatially explicit agent- 
based model. Land Use Policy 30:934-943. http://dx.doi. org/10.1016/j.landusepol.2012.06.008

Stewart, G. B., C. F. Coles, and A. S. Pullin. 2005. Applying evidence-based practice in conservation management: lessons from the first systematic review and dissemination projects. Biological Conservation 126:270-278. http://dx.doi.org/10.1016/j. biocon.2005.06.003

Taylor, M. E., and M. D. Morecroft. 2009. Effects of agrienvironment schemes in a long-term ecological time series. Agriculture, Ecosystems \& Environment 130:9-15. http://dx.doi. org/10.1016/j.agee.2008.11.004

Thompson, F. R., III, and R. M. DeGraaf. 2001. Conservation approaches for woody, early-successional communities in the eastern United States. Wildlife Society Bulletin 29:483-494.

van Swaay, C., M. Warren, and G. Loïs. 2006. Biotope use and trends of European butterflies. Journal of Insect Conservation 10:189-209. http://dx.doi.org/10.1007/s10841-006-6293-4

Van Teeffelen, A. J. A., C. C. Vos, and P. Opdam. 2012. Species in a dynamic world: consequences of habitat network dynamics on conservation planning. Biological Conservation 153:239-253. http://dx.doi.org/10.1016/j.biocon.2012.05.001

Vatn, A., and P. Vedeld. 2012. Fit, interplay, and scale: a diagnosis. Ecology and Society 17(4):12. http://dx.doi.org/10.5751/ es-05022-170412

Wahlberg, N. 1997. The life history and ecology of Melitaea diamina (Nymphalidae) in Finland. Nota Lepidopterologica 20:70-81.

Wahlberg, N. 1998. Suomen uhanalaisia lajeja: tummaverkkoperhonen (Melitaea diamina). Suomen Ympäristö 168. Suomen Ympäristökeskus, Helsinki, Finland.

Walker, B., C. S. Holling, S. R. Carpenter, and A. Kinzig. 2004. Resilience, adaptability and transformability in social-ecological systems. Ecology and Society 9(2):5. http://dx.doi.org/10.5751/ es-00650-090205

Young, O. R. 2003. Environmental governance: the role of institutions in causing and confronting environmental problems. International Environmental Agreements: Politics, Law and Economics 3:377-393. http://dx.doi.org/10.1023/b:

inea.0000005802.86439.39 


\section{Appendix 1. Thematic interview frameworks of conservation professionals}

\section{PROFESSIONALS OF ELY CENTERS}

\section{Conservation responsibility}

1. What does the conservation responsibility of the false heath fritillary mean to you, where does such a responsibility come from and what is the concrete aim that conservation activities are targeting at?

2. What does legislation say about the conservation of the false heath fritillary?

3. Are there additional institutional guidelines to civil servants related to the conservation responsibility?

\section{Charting of the need for conservation activities in the ELY centers}

1. How do you evaluate the annual need for conservation activities and how they are realized?

2. How do you plan the implementation of the above mentioned conservation activities?

3. How do you assess the effectiveness of alternative maintenance options?

4. To which extent do you assess the development of the habitat patch network as an entity?

5. Does the number of maintained habitats vary according to the year? On what basis?

6. How much resources do you have for the assessment of the conservation need of this species? (Alternatively, how a big share of the resources you have are used by other species and tasks and how much is left for this species?)

\section{The assessment of conservation need elsewhere}

1. Do you get guidance or instructions for the false heath fritillary conservation from elsewhere?

2. Do you co-operate with other ELY centers regarding the conservation planning?

\section{Co-operation}

1. What types of backgrounds do the landowners of false heath fritillary habitats have?

2. How big a part (by estimation) of the meadow landowners are positive about meadow conservation?

3. What kind of means do you have for arranging maintenance at particular habitat sites?

4. How much resources do you have available for landowner co-operation?

5. How efficient it is to motivate landowners with money? How efficient is information sharing?

6. Are the current funding mechanisms suitable for the meadow landowners? 


\section{Changing situations}

7. What generates the options for site maintenance? How much do you have resources to estimate the benefits of alternative means? How do you make a choice among available options?

8. Please give examples on situations where original plans have needed to be adjusted to changing situations (e.g. changes in landownership, changes in governmental guidance, changes in cooperation networks)

\section{Application of funding in the ELY center}

1. What sources of funding does the ELY center have for false heath fritillary conservation?

\section{Describe for each funding source:}

2. Where does the funding come from and where is the application sent?

3. Do you know who processes the application?

4. How is the funding application justified? Are the same justifications listed annually?

5. At what time of year is the application being made and when do the decisions arrive? Is the timing good for making plans with landowners? Is there enough of time left for planning?

6. How much do you know of the decision-making grounds that have affected the amount of funding you get? If any, what are the influential factors affecting money allocation?

7. Do the funding decisions seem well justified?

8. For what other species does your ELY center apply for similar funding?

\section{Application of funding by the landowners}

1. What sources of funding do the landowners have for false heath fritillary conservation?

\section{Describe for each funding source:}

2. Where does the funding come from and where is the application sent?

3. Do you know who processes the application?

4. How is the funding application justified? Are the same justifications listed annually?

5. At what time of year is the application being made and when do the decisions arrive? Is the timing good for making plans with landowners? Is there enough of time left for planning?

6. How much do you know of the decision-making grounds that have affected the amount of funding you get? If any, what are the influential factors affecting money allocation?

7. Do the funding decisions seem well justified?

8. For what other species does your ELY center apply for similar funding?

\section{The outcome}

1. How well does the realized set of managed sites match with which sites should have been protected and maintained within your ELY center?

2. How well does the conservation status of the false heath fritillary match with the targeted "favorable conservation status"?

3. If not, how much resources would be needed to reach the favorable conservation status?

4. What tools or means should be allowed to the ELY centers so that the favorable conservation status could be met with a socially meaningful way? 


\section{PROFESSIONALS OF GOVERNMENTAL INSTITUTIONS: MINISTRY OF THE ENVIRONMENT}

\section{Funding instruments available for species conservation}

1. What kind of funding instruments are available for the financing of the conservation of species of strict protection and species in need of urgent conservation?

2. How much do the funds vary annually that can be allocated from such clauses, and why?

3. By what process are the sums allocated from each clause decided on?

\section{The application process}

1. Who can apply for funding from the above mentioned clauses and with what kind of restrictions or requirements?

2. How many funding applications do you get annually? What kind of institutions send applications?

3. Are the funding applications usually adequately precise?

\section{The assessment of applications}

1. On your opinion, what are the most important uses of the above mentioned budget clauses?

2. Who decides how the money is being distributed among applicants?

3. On what basis are the applications prioritized and the allocated sums of money decided? What aspects are assessed in the applications? Is the decision-making founded on the information included in the applications, or on the results of the prioritization meetings or also on other sources?

4. Is the decision-making influenced by regional priorities or by previous years' funding decisions? (E.g. is it possible to follow long-term priorities and, in the case of individual species, is there an estimation how much money is allocated between regions?)

5. Is the decision-making affected by the applicant's possibility to retrieve funding from other sources?

\section{Information sharing}

1. Who informs the applicants on the funding decision?

2. How are the funding decisions grounded to the applicants? Does the funding decision contain recommendations on the use of allocated funds?

\section{The outcome}

1. Are you satisfied with how the purpose of the above mentioned budget clauses are being met, the amount of available funding and the process of funding allocation? 


\section{Species of strict conservation}

1. What does the conservation responsibility of the species of strict conservation concern mean to you, what is the concrete goal of the conservation activities and on who's responsibility is it to plan (a) the meeting of the favorable conservation status, (b) maintenance activities needed?

2. What would you like to improve in the process of funding allocation related to the species of strict conservation concern?

3. How should the maintenance of habitats that suffer from habitat overgrowth be organized?

4. What tools or resources should be enables for the ELY centers, so that the favorable conservation status of the false heath fritillary could be met in a socially meaningful way?

\section{PROFESSIONALS OF GOVERNMENTAL INSTITUTIONS: FINNISH ENVIRONMENT INSTITUTE (SYKE)}

\section{Prioritization meetings}

1. What is the origin and target of the regional prioritization meetings?

2. Who is responsible of the prioritization meetings and who take part in the meetings?

3. Which species are discussed in the prioritization meetings (VU, EN, CR)? How is it decided which species are classified as species in need of urgent conservation (assuming this is a different classification than species of strict protection)?

4. How often have meetings been organized for each taxon, or how often are they planned to be organized?

\section{Practicalities of prioritization}

1. Who decides how species are prioritized?

2. On what basis are species prioritized? How are decisions made among multiple experts? Is the decision-making founded on the information included in the annual endangered species funding applications, information outcomes of the prioritization meetings, data of national species databases or also on additional sources?

3. Is the decision-making influenced by regional priorities or by previous years' funding decisions? (E.g. is it possible to follow long-term priorities and, in the case of individual species, is there an estimation how much money is allocated between regions?)

\section{Targets of the prioritization meetings}

1. What kind of actions are supposed to be taken on the basis of prioritization meetings in the case of high-priority species that need habitat maintenance? (Funding allocations, internal resource use in the ELY centers)

2. To what extent do the outcomes of the prioritization meetings affect the allocation of conservation funding in the national level? 
3. Is the target of prioritization meetings to improve the conservation status of the prioritized species so much that eventually they would no longer need urgent conservation measures?

\section{The outcome}

1. Are you satisfied with the realization of the conservation measures agreed in the prioritization meetings, the amount of available conservation funding and the process of funding allocation?

2. Should the allocation of habitat maintenance funding for endangered species be based on something else than the outcomes of the prioritization meetings? If yes, what?

\section{Species of strict conservation}

1. What does the conservation responsibility of the species of strict conservation concern mean to you, what is the concrete goal of the conservation activities and on who's responsibility is it to plan (a) the meeting of the favorable conservation status, (b) maintenance activities needed, (c) overall conservation planning?

2. Which funding instrument should be used to cover the habitat maintenance costs of endangered species that are threatened by habitat overgrowth? For (a) private agricultural land, (b) private conservation areas, (c) publicly owned land?

3. What tools or resources should be enables for the ELY centers, so that the favorable conservation status of the false heath fritillary could be met in a socially meaningful way?

4. For how many other species is habitat overgrowth the primary threat? 